Cognition, communication, discourse.

2020, 21: 36-49.

http://sites.google.com/site/cognitiondiscourse/home

https://doi.org/10.26565/2218-2926-2020-21-03

UDC 811.111’42

\title{
COGNITIVE PRAGMATICS OF AMERICAN PRESIDENTIAL DEBATES: A CASE FOR ECONOMIC METAPHORS
}

Iryna Shevchenko

(V. N. Karazin Kharkiv National University, Kharkiv, Ukraine)

Tamara Goncharova

(Kazimierz Wielki University, Bydgoszcz, Poland)

Volodymyr Gutorov

(V. N. Karazin Kharkiv National University, Kharkiv, Ukraine)

\begin{abstract}
I. Shevchenko, T. Goncharova, and V. Gutorov. Cognitive pragmatics of American presidential debates: a case for economic metaphors. This article focuses on cognitive-pragmatic properties of conceptual metaphors of ECONOMY in the $21^{\text {st }}$ century American presidential campaigns. In this paper, we aim to elaborate the models of metaphoric conceptualization of ECONOMY, state their functions in terms of discourse strategies, and describe their impact on the opponents and the audience. This research is underpinned by conceptual metaphor theories and ideas of cognitive pragmatics, which postulates the unity of cognitive and communicative aspects of discourse. The benefits of this integrative cognitive-pragmatic approach are in the fact that it can consequently explicate the meaning of speaker's message and the expected impact of their discourse on the audience. For this aim, we stress the persuasive and manipulative nature of American presidential debates as a mass-media mediated genre of political discourse. Adopting a cognitive-pragmatic perspective on presidential debates, we claim that conceptual metaphors of ECONOMY constitute time and ideology specific conceptual models; their dominant functions are persuasive, informative, and manipulative. In the discourse of the $21^{\text {st }}$ century presidential debates, we distinguish seven leading models of conceptual metaphors of ECONOMY, common for both republican and democratic candidates. The choice of discourse strategies of debate participants depends upon the candidates' intentions while their impact on the opponent and the audience is influenced by meta-communicative issues of candidates' communicative behavior and (im)politeness strategies in particular. The $21^{\text {st }}$ century presidential debates are characterized by the abundance of discourse strategies of aggression and impoliteness.
\end{abstract}

Key words: conceptual metaphor of ECONOMY, cognitive-pragmatic analysis, presidential debate, discourse strategy, (im)politeness.

І. Шевченко, Т. Гончарова, В. Гуторов. Когнітивна прагматика американських президентських дебатів: аналіз метафор ЕкономІкИ. У цій статті розглядаються когнітивно-прагматичні властивості концептуальних метафор ЕКОНОМІКИ в американських президентських кампаніях XXI століття. Ця стаття присвячена розробці моделей метафоричної концептуалізації ЕКОНОМІКИ, виявленню їх функцій у термінах дискурсивних стратегій і опису їх впливу на опонентів і аудиторію. В основі цього дослідження лежать теорії концептуальної метафори та ідеї когнітивної прагматики, які постулюють єдність когнітивних і комунікативних аспектів дискурсу. Переваги цього інтегративного когнітивно-прагматичного підходу полягають у тому, що він здатний пояснити значення висловлювання мовця і очікуваний вплив його дискурсу на аудиторію. Для досягнення своєї мети стаття фокусується на персуазивному i маніпулятивному характері президентських дебатів як жанру політичного дискурсу, опосередкованого ЗМІ. Використовуючи когнітивно-прагматичне трактування президентських дебатів, ми стверджуємо, що концептуальні метафори ЕКОНОмІки є концептуальними моделями, специфічними для певного часу і ідеології; їх домінуючі функції - персуазивна, інформативна і маніпулятивна. У дискурсі президентських дебатів XXI століття ми виділяємо сім провідних моделей концептуальних метафор ЕКонОмІки, спільних як для кандидатів-республіканців, так і для демократів. Вибір певних дискурсивних стратегій учасників дебатів залежить від намірів кандидатів, в той час як їх вплив на опонента і аудиторію залежить від метакомунікативних аспектів комунікативної поведінки кандидатів, зокрема, стратегій (анти)ввічливості. Встановлено, що президентські дебати XXI століття характеризуються великою кількістю дискурсивних стратегій агресії і (анти)ввічливості.

Ключові слова: концептуальна метафора ЕКономІки, когнітивно-прагматичний аналіз, президентські дебати, стратегія дискурсу, (анти)ввічливість.

(C) Shevchenko I., Goncharova T., Gutorov V., 2020 
И. Шевченко, Т. Гончарова, В. Гуторов. Когнитивная прагматика американских президентских дебатов: анализ метафор экономики. В данной статье рассматриваются когнитивно-прагматические свойства концептуальных метафор экономики в американских президентских кампаниях XXI века. Статья посвящена выявлению моделей метафорической концептуализации эКОномики, определению их функций в терминах дискурсивных стратегий и описанию их влияния на оппонентов и аудиторию. В основе этого исследования лежат теории концептуальной метафоры и идеи когнитивной прагматики, которые постулируют единство когнитивных и коммуникативных аспектов дискурса. Преимущества этого интегративного когнитивнопрагматического подхода заключаются в том, что он способен объяснить значение высказывания говорящего и ожидаемое влияние его дискурса на аудиторию. С этой целью статья фокусируется на персуазивном и манипулятивном характере президентских дебатов как жанре политического дискурса, опосредованного СМИ. Используя когнитивно-прагматическую трактовку президентских дебатов, мы утверждаем, что концептуальные метафоры эКОНОмики представляют собой концептуальные модели, специфичные для определенного времени и идеологии; их доминирующие функции - персуазивная, информативная и манипулятивная. В дискурсе президентских дебатов XXI века мы выделяем семь ведущих моделей концептуальных метафор экОНОмИки, общих как для кандидатов-республиканцев, так и для демократов. Выбор определенных дискурсивных стратегий участников дебатов зависит от намерений кандидатов, в то время как их влияние на оппонента и аудиторию зависит от метакоммуникативных аспектов коммуникативного поведения кандидатов, в частности, стратегий (анти)вежливости. Установлено, что президентские дебаты XXI века характеризуются обилием дискурсивных стратегий агрессии и антивежливости.

Ключевые слова: концептуальная метафора экОНОМИКИ, когнитивно-прагматический анализ, президентские дебаты, стратегия дискурса, (анти)вежливость.

\section{Introduction}

The issues of political discourse are increasingly drawing the researchers' attention in cognitive linguistics (Lakoff, 1996) and pragmatics (Schmid, 2012). Presidential debates play a leading role in the acquisition of political knowledge during presidential campaigns, defining salience of certain issues and vote choice. Citizens learn about candidates and their stances from debate viewing (Feldman \& Price, 2008). Economic issues retain their importance in all presidential campaigns irrespective of time and leading party programs and slogans.

In presidential debates, their global intention to achieve power is realized through the local intentions of creating an attractive image of the candidate for the presidency with the help of presentation strategies and tactics aimed at modifying the electorate's worldview by implanting the basic concepts of the candidate's worldview into it. This unity of cognitive and pragmatic issues defines the choice of cognitive pragmatics as the basic methodology in our analysis. In this paper, we aim at characterizing the strategies of American presidential debate and identifying the semantic-pragmatic interface of construing metaphoric meaning-in-context for conceptual metaphors of ECONOMY. Our analysis is underpinned by cognitive-pragmatic understanding of discourse strategies and the construal of meaning-in-context involving cognitive metaphor theory (Kövecses, 2002), conceptual blending theory (Coulson \& Oakley, 2005), (im)politeness theories (Culpeper, n.d.; Shevchenko \& Petrenko, 2019), etc.

After this introduction, to reach this aim we briefly discuss the methods used to study cognitive metaphors, describe the steps of our research methodology, argue why the proposed methodology is needed, and describe the data and the illustrative material (section 2). Then we define the conceptual economic metaphors and related metonymies in American presidential debates of the $21^{\text {st }}$ century (section 3 ) and use the data obtained to analyze their functioning in economic segments of debates in terms of discourse strategies, and describe their impact on the opponent and the audience (section 4). Finally, we sum up and evaluate the results, and suggest perspectives for further analyses (section 5).

\section{Method and Material}

Drawing on cognitive-pragmatic view of meaning-in-context the paper uses empirical material to argue that, in presidential debates, the facilitation of persuasive impact on the audience is a matter not only of specific use of the candidates' discourse-generative concepts (the key concepts of their 
election programs) but also of specific manner of discussion (in particular, discourse principles of communicative behavior).

Today, a cognitive-pragmatic approach satisfies the need of linguistics to complement the cognitive approach with pragmatic and socio-cultural dimensions of inquiry. It should be mentioned that pragmatics is cognitive by nature. Treated against psychological (cognitive-science), philosophical and sociological backgrounds Gricean conversational principles, Searlean speaker's intentions, and Sperber and Wilson's relevance-theoretical framework are inwardly cognitive. The pragmatic principle of relevance has been a cornerstone for the understanding of other principles and implicatures as it explains the way of construal of "what is meant" (meaning-in-context) on the basis of "what is said".

Speaking of 'cognitive pragmatics' Carston (2002, p. 11) defines it as an "explanatory account of a specific performance mechanism conducted at the level of representations-andprocedures". Taking a broad understanding of the term we treat cognitive pragmatics as a multidisciplinary approach of linguistic pragmatics integrating cognitive and communicative (pragmatic) discourse studies (Shevchenko \& Gutorov, 2019). Applied to the study of non-literal language, cognitive pragmatics reveals the role of metaphors and metonymies in spoken and written discourse (Deignan, 2012).

Cognitive-pragmatic framework of analysis highlights the interconnection rather than juxtaposition of the cognitive-linguistic and pragmatic dimensions of discourse. In this framework, our cognitive-pragmatic analysis of metaphors of ECONOMY includes a few consequent stages, a conceptual and a pragmatic one.

The political discourse of presidential campaigns is a system of linguistic, cognitive, communicative, axiological, and pragmatic aspects; it is characterized as institutional, information modifying, persuasive, theatrical and authoritarian with a significant role of mass-media (Horyna, 2008). To reached the persuasive aim of presidential campaigns the candidate transforms the voters' worldviews by implanting into them the basic concepts of the candidate' worldviews. In political discourse, this aim is achieved by specific communicative strategies and tactics (Horyna, 2008), which need specific methods of analysis (Goncharova, 2009, 2010).

In his study of how liberals and conservatives think, Lakoff (2002) claims that conceptual metaphor is an important part of our though process and of pursuing politicians' interests in their public discourse. As one of the basic operations of human cognition, conceptual metaphor implies the correlation of an abstract and a more specific concept or domain. "In the process of mapping, a concept/conceptual domain, identified with the help of a metaphor, acts as a target concept/domain or conceptual referent; a concept/conceptual domain, used for comparison acts as a source concept/domain or conceptual correlate" (Lakoff, 1993, p. 203, 245). Some conceptual elements of a source domain correspond to those of a target domain; they are referred to as cross-mappings (Lakoff, 1993, pp. 206-207).

"A mapping, or mental space connection, is the understanding that an object or element in one mental space corresponds to an object or element in another" (Coulson \& Oakley, 2005, p. 1513). Conceptual elements are revealed by the operation of 'highlighting/hiding' (Lakoff \& Johnson, 1999, pp. 13-16): certain properties of the referent that are relevant to the context are 'highlighted' and others are 'hidden' (remain unused). They can be grouped into appropriate metaphorical models by logical reasoning. The interaction of two concepts or conceptual complexes in a conceptual metaphor takes place on the basis of some common properties and results in the form “CONCEPT/CONCEPTUAL DOMAIN A IS CONCEPT/CONCEPTUAL DOMAIN B” (Kövecses, 2002, p. 4; Lakoff \& Johnson, 1980, p. 1).

In theories of conceptual integration or blending (Fauconnier \& Turner, 2002), metaphor is viewed as a process of comprehending abstract concepts via concrete ones. Turner (1996) argues that 'input spaces $_{1,2}$ ' are cross-mapped into 'generic' space possessing elements common to both 
input spaces and finally into a 'blended' space, which unites elements from both input spaces into a new conceptual structure of its own (Turner, 1996).

Lakoff (2013) claims that metaphors have a great impact on society, they can kill:

Why can metaphors kill? Because metaphors in language are reflections of metaphorical thought that structures reasoning, and thus our actions, both in everyday life and in politics. In politics, they are rarely isolated. They usually come as part of a coherent system of concept-usually a moral system.

In political discourse, metaphors reflect the nation's linguistic worldview dominated by current political issues. Conceptual metaphor helps to interpret the ideological values, most of which are abstract concepts. In this article, we focus on the models of cognitive metaphors of ECONOMY as a target domain and their functioning in discourse. Such metaphors make political discourse more effective because they allow comprehending abstract issues in terms of concrete ones.

Metaphor is not the sole means of figurative language. Within the framework of conceptual metonymy (Radden \& Kövecses, 1999; Barcelona, 2000), both metaphor and metonymy are viewed as means of structuring thought and language. Metonymy is a conceptual projection of one domain onto another, which is part of the same original domain (Barcelona, 2000, p. 4). The metonymic transfer is based on the principle of contiguity unlike metaphor, which is based on the principle of similarity. In case of interaction between metaphor and metonymy, the result is metaphtonymy (Barcelona, 2000), a cognitive mechanism that combines the two former techniques.

To reach the two-fold aim of this paper our analysis has two main stages. First, at the cognitive stage, we define the conceptual space of ECONOMY through the semantic study of lexemes - direct nominations of this concept in Modern English dictionaries and thesauri (Collins English Dictionary, n.d..), characterize the emergence of the concept figurative meaning-in-context in terms of classical metaphor theory (Kövecses, 2002; Lakoff, 1993) and blending theory (Coulson \& Oakley, 2005; Fauconnier \& Turner, 2002), and single out the leading models of conceptual metaphors of ECONOMY in discourse. Since we focus on conventional metaphors our main method is the lexical method. Then, at the pragmatic stage of analysis, we explicate discursive functions of the concept of ECONOMY in presidential debates with the help of intentional analysis (Goncharova, 2009), and methods of critical discourse analysis (van Dijk, 2008), which are understood against the (im)politeness principles.

The present study used the data taken from American presidential debates of 2000-2020. In most of them, the formats and rules gave equal chances for the parties to air their views on American and world economy; their moderator was Jim Lehrer of the NewsHour on PBS. In this article, the scope of illustrative material is limited to examples of cognitive metaphors and metonymies of ECONOMY. The illustrations are mainly taken from the textual transcripts provided by The Commission on Presidential Debates for

- the first Gore-Bush Presidential Debate of 2000, which took place in Boston between the Democratic candidate for president, Vice President Al Gore and the Republican candidate, Governor George W. Bush of Texas (The Commission on Presidential Debates, 2000);

- $\quad$ the Second Bush-Kerry Presidential Debate of 2004 in St. Louis (moderator Charles Gibson of ABC News and Good Morning America) (The Commission on Presidential Debates, 2004b);

- $\quad$ the first presidential debate of 2008 between the Republican nominee, Senator John McCain of Arizona, and the Democratic nominee, Senator Barack Obama of Illinois (The Commission on Presidential Debates, 2008). The debate was devoted to the topics of foreign policy and national security; by definition, it included the global financial crisis;

- the first presidential debate of 2012 between President Barack Obama, the Democratic nominee, and former Massachusetts Governor Mitt Romney, the Republican nominee, in Denver (The Commission on Presidential Debates, 2012); 
- the first presidential debate of 2016 in New York between Hillary Clinton, a Democratic nominee for president of the United States, and Republican nominee Donald J. Trump (The Commission on Presidential Debates, 2016);

- $\quad$ the first of the 2020 Presidential Debates between President Donald J. Trump and former Vice President Joe Biden (The Commission on Presidential Debates, 2020) (moderator Chris Wallace of Fox News) in Cleveland.

\section{Conceptual metaphors of ECONOMY as mental models}

The conceptual space of ECONOMY is determined by the semantic properties of lexemesnominations of this concept: economy (n.) and its synonyms-financial system, financial state, thrift, saving, restraint, prudence, providence, husbandry, retrenchment, frugality, parsimony, thriftiness, sparingness (Collins English Dictionary, n.d.). In Modern English dictionaries (Collins English Dictionary, n.d.), the scope of semantic properties of economy $(n)$ includes three hypersemes 'economic system', 'management', and 'frugality'. They are characteristic of the units of a lexico-semantic field 'Economy' and motivate three corresponding micro fields:

- micro field 'Economic System' has two extensions:

"branch of economic system" (trade, finance, agriculture, manufacturing, farming) and "type of economic system" (market, top down, command, mixed, black, grey, macro, micro, individual, collective economy, global economy, socialism);

- micro field 'Management' embraces extensions:

"regulation" ("an organized system or method", lexemes acts, reforms, budgetary control, management);

"economic doctrine" ("a belief, principle, or doctrine or a code of beliefs, principles or doctrines", synonymes dogma, socialism, capitalism, theory, theorist);

- micro field 'Frugality' meaning "moderate or sparing expenditure or use of provisions, goods, etc." includes two extensions:

"thrift" - "savings, deposits, capital, down-market, low-priced, low-budget, budget goods", "saver" meaning both a person-saver and something that makes it possible to spend less money / ways of saving money (Collins English Dictionary, n.d.) (lexemes deliverer, saviour, hoarder, possessor, economizer, owner).

The elements of this lexico-semantic field structure the concept of ECONOMY according to propositional schemes. Zhabotynska (2013) claims that the information activated by these lexemes forms 'conceptual nets'. Her method of 'linguistic net semantics' (Zhabotynskaya, 2013) allows to determine the conceptual net of ECONOMY. In the discourse of the $21^{\text {st }}$ century presidential debates, the dominant schemes of the concept of ECONOMY embrace: existential scheme (qualitative, locative, temporal, and scheme of mode); actional (state/process); possessive; identificational (classification), and comparative (analogy) schemes:

- possessive scheme "OW-nation has OD-economy" (The American economy);

- scheme of mode "X-economy exists AS-crisis" (economic crisis, economic downturn);

- scheme of classification "ID/type-economy is CL/sub-type" (our economy, this economy);

- locative scheme "Y-economy is WHERE/LC-place" (market economy on the Continent; global economy);

- temporal scheme "Y-economy is WHEN/TM-time" (current management, Obama recession);

- scheme of quality "Y-economy is SUCH-quality" (strong economy, great economy);

- scheme of state / process "AG-economy ACTS" (developing economy, falling economy);

- scheme of analogy "CV-economy is as AN-other economy" (the Georgian economy, the Great Depression-like crisis).

The conceptual metaphors of ECONOMY are highly conventionalized. In the $21^{\text {st }}$ century presidential debates, we distinguish seven leading models of conceptual metaphors of ECONOMY. 
Among them, personification $(42.1 \%)$ prevails over structural metaphors. The cognitive function of these metaphors is to enable understanding the target in terms of a living being. In the conceptual worldview, person is typically endowed with the ability to move (raise, decline, slow down, leave) (1a-d), to take certain actions (2), to recover (3), etc.:

(1a) Kerry: In addition to that, I believe we have a crisis here at home, a crisis of the middle class that is increasingly squeezed, health-care costs going up...

(The Commission on Presidential Debates, 2004b)

(1b) Bush: The stock market was declining six months prior to my arrival. Non-homeland, nondefense discretionary spending was raising at 15 percent a year when I got into office.

(The Commission on Presidential Debates, 2004b)

(1c) Obama: And because of the economy's slowing down, I think we can also expect less tax revenue...

(The Commission on Presidential Debates, 2008)

(1d) Trump: Well, the first thing you do is don't let the jobs leave. The companies are leaving.

(The Commission on Presidential Debates, 2016)

(2) Gore: ... some of our most precious environmental treasures, like the Arctic National Wildlife Refuge for the big oil companies to go in and start producing oil there. $<\ldots>$

I know the oil companies have been itching to do that, but it is not the right thing for the future.

(The Commission on Presidential Debates, 2000)

(3) Wallace: The economy is, I think it's fair to say, recovering faster than expected from the shutdown-

(The Commission on Presidential Debates, 2016)

In structural metaphors, the target domain of ECONOMY provides a rich space of knowledge for source concepts. The 'weight' of such source concepts differs: they form conceptual metaphors ECONOMY IS AN ARTIFACT (22.6\%), ECONOMY IS A PLANT (18.5\%), ECONOMY IS MEDICINE (5.5\%), ECONOMY IS WAR (5.0\%), and ECONOMY IS AN ANIMAL (3.1\%).

ECONOMY IS AN ARTIFACT. This conceptual metaphor is based on the source domain-or rather domain matrix-ARTIFACT. "A domain as a domain matrix (such as BUILDING) presupposes a variety of concepts that characterize different aspects of a domain" (Kövesces, 2017, p. 325). The domain matrix ARTIFACT includes a vast number of concepts, which participate in the crossmapping: GAP, BURDEN, CAR, TUNNEL, MIRROR, BALLOON, BUBBLE, etc, (4a-h), and PHYSICAL OBJECT with changeable parameters (5a-e), e.g.,

ECONOMY IS A GAP or BURDEN:

(4a) Bush: It's like a huge tax gap.

(The Commission on Presidential Debates, 2004a)

(4b) Varner: Senator Kerry, would you <...> give the American people your solemn pledge not to sign any legislation that will increase the tax burden on families earning less than $\$ 200,000 \mathrm{a}$ year during your first term?

(The Commission on Presidential Debates, 2004b)

ECONOMY IS A CAR (in a car, one can start its engine, drive it out, etc.):

(4c) Kerry: He came and asked for a tax cut-we wanted a tax cut to kick the economy into gear.

(The Commission on Presidential Debates, 2004b)

(4d) Trump: You are going to approve one of the biggest tax increases in history. You are going to drive business out.

(The Commission on Presidential Debates, 2016)

ECONOMIC CRISIS IS A TUNNEL, one can move through it:

(4e) Obama: You know, four years ago we went through the worst financial crisis since the Great Depression.

(The Commission on Presidential Debates, 2012) 
ECONOMIC DEFICIT IS A BALLOON, which can be blown up, or a BUBBLE:

(4f) Obama: We can afford to do a little bit more to make sure we're not blowing up the deficit.

(The Commission on Presidential Debates, 2012)

(4g) Trump: We're in a bubble right now. $<\ldots>$ We are in a big, fat, ugly bubble. And we better be awfully careful.

(The Commission on Presidential Debates, 2016)

BUDGET IS A MIRROR, which can reflect items:

(4h) Obama: And so budgets reflect choices.

(The Commission on Presidential Debates, 2012)

ECONOMY IS A PHYSICAL OBJECT, which can be balanced; its parameters can be altered:

(5a) Romney: That's how we get growth and how we balance the budget. $<\ldots>$ You'll never balance the budget by raising taxes.

(The Commission on Presidential Debates, 2012)

(5b) Biden: He hasn't lowered drug costs for anybody. (The Commission on Presidential Debates, 2020)

(5c) Obama: On energy, Governor Romney and I, we both agree that we've got to boost American energy production...

(The Commission on Presidential Debates, 2012)

ECONOMY IS A PHYSICAL OBJECT/THING, which can be lost, raised, closed, and reopened, etc.:

(5d) Kerry: Now, the president has presided over an economy where we've lost 1.6 million jobs. The first president in 72 years to lose jobs. (The Commission on Presidential Debates, 2004b)

(5e) So we built the greatest economy in history. We closed it down because of the China plague. $<\ldots>$ and now we're reopening and we're doing record business.

(The Commission on Presidential Debates, 2020)

The source domain matrix PLANT cross-mapped onto the target concepts of TAXES / RATES creates conceptual metaphors ECONOMY IS A PLANT. In this domain matrix, various aspects participate in cross-mapping with the target domain: the aspect of growth (6a-b) and the aspect of trimming (cutting) (7a-c). The latter makes 'tax cut', or 'slashing taxes' one of the most frequent conceptual metaphors in the discourse of both democrats and republican candidates, e.g.:

(6a) Gore: I will help parents and strengthen families because, you know, if we have prosperity that grows and grows, we still won't be successful unless we strengthen families by...

(The Commission on Presidential Debates, 2000)

(6b) Obama: So my attitude is, we've got to grow the economy from the bottom up.

(The Commission on Presidential Debates, 2008)

(7a) Bush: I want everybody who pays taxes to have their tax rates cut.

Gore: Every middle class family is eligible for a tax cut under my proposal.

(The Commission on Presidential Debates, 2000)

(7b) Our country has cut the welfare rolls in half. I fought hard from my days in the Senate and as vice president to cut the welfare rolls and we've moved millions of people in America into good jobs.

(The Commission on Presidential Debates, 2000)

(7c) Kerry: And to do the job, you can't cut the money for it. The president actually cut the money for it.

(The Commission on Presidential Debates, 2004a)

Conceptual metaphor ECONOMY IS MEDICINE is a result of cross-mapping of abstract concepts ECONOMY, MARKET, etc. and perception-based ones like RECIPE: 
(8a) McCain: ...not raising anyone's taxes is probably the best recipe for eventually having our economy recover.

(The Commission on Presidential Debates, 2008)

(8b) Obama: Even if we get all $\$ 700$ billion back, let's assume the markets recover, we'holding assets...

(The Commission on Presidential Debates, 2008)

(8c) Romney: ...the tax break for oil companies is $\$ 2.8$ billion a year. And it's actually an accounting treatment ...

(The Commission on Presidential Debates, 2012)

In the conceptual metaphor ECONOMY IS WAR, different entities of the domain of WAR (ENEMY, FIGHT) are cross-mapped onto target concepts, e.g.,

(9) McCain: Who fought against wasteful and earmark spending?

(The Commission on Presidential Debates, 2008)

The conceptual metaphor ECONOMY IS AN ANIMAL in presidential debates results from crossmapping of the information connected with the concept of HORSE or SWINE (it can be guided by reins, it feeds from a pork-barrel, etc.):

(10) McCain: That kind of thing is not the way to rein in runaway spending in Washington, D.C. $<\ldots>$ And we have former members of Congress now residing in federal prison because of the evils of this earmarking and pork-barrel spending.

(The Commission on Presidential Debates, 2008)

Orientation conceptual metaphors ECONOMY IS UP/DOWN (3.2\%) present the downward or upward vectors of the target:

(11) Obama: Now, John mentioned the fact that business taxes on paper are high in this country, and he's absolutely right. $\langle\ldots>$ we actually see our businesses pay effectively one of the lowest tax rates in the world. $\quad$ (The Commission on Presidential Debates, 2008)

In presidential debates, there are a few most common types of metonymy connected with ECONOMY. They involve the highlighting of the relevant part of the target domain. Hill (2013, p. 112) describes such cases as the target-in-source metonymy; among them part-whole and space-temporal ones. Metonymy LOCATION FOR AN OFFICE/INSTITUTION mostly highlights economic offices and institutions in Washington and New York (WASHINGTON stands for GOVERNMENT):

(12) Obama: I mean, we've had years in which the reigning economic ideology has been what's good for Wall Street, but not what's good for Main Street.

(The Commission on Presidential Debates, 2008)

Synecdoche PART FOR THE WHOLE, in presidential debates, highlights money issues:

(13) Kerry: The president hasn't put one nickel, not one nickel into the effort to fix some of our tunnels and bridges and most exposed subway systems.

(The Commission on Presidential Debates, 2004a)

The manifestation of metonymy PEOPLE RESPONSIBLE FOR INSTITUTION mostly names LEADER FOR HIS COUNTRY in economic transactions:

(14) Bush: Today we import one million barrels from Saddam Hussein.

(The Commission on Presidential Debates, 2000) 
Both cognitive metaphor and metonymy are means of communication based on shared knowledge. The use of these means of figurative language is well prepared by speechwriters and specially meant to be understood by the audience. They help understand discourse strategies of presidential debates.

\section{Conceptual metaphors of ECONOMY as discourse strategies}

Being of the institutional nature, presidential debate is a specific genre of electoral discourse; it is limited to situations of institutional communication and has a persuasive nature. In debates, the presentation function of candidates is realized through informative strategies of modifying the voters' worldviews by implanting the basic concepts of the candidate and their party. The latter is also achieved by widely used manipulative strategies (Horyna, 2008).

The debates are of a double dialogical nature: on the one hand, it is the communication of the candidates with each other; on the other, it is a message to the audience mediated by mass media. Accordingly, the candidate's communicative behavior has three vectors, which differ in their aims. The first vector aims at suppressing the opponent; the second aims at 'capturing' an audience, the third aims at appealing to the mass media. The role of mass-media as a mediating factor distinguishes debates from other genres of the US presidential campaigns. To paraphrase McLuhan, in presidential debates 'the medium' is no less important than 'the message'.

In political discourse, its global goal or a super task is to win and hold on to power (Chouliaraki, 2000). In presidential debates, the candidate's global intention to achieve power is realized through local intentions of creating an attractive image of the candidate for the presidency. The leading tactics are: self-presentation, discrediting the opponent, meaningful analysis and assessment of the situation, self-defense; strategies of motivation and manipulation, which tend to be implemented in the form of a cluster.

The informative and persuasive goals of the candidates include self-presentation and presentation of their programs, an analysis of the situation, criticism and discreditation of the opponent, encouragement to vote for the candidate, warning and exposure, self-justification. In debates, the candidates' presentational function is realized through their information-oriented tactics of modifying the voters' worldview. As Lakoff (2011, no page numbers) claims,

There are two aspects to policy: cognitive and material. Material policy is about the nuts and bolts, how things are to work in the world. Cognitive policy is about what the public has to have in its brain/mind in order to fully support the right material policies. Coal, nuclear energy, and ethanol are policy disasters, and even giving them support with nuanced escape clauses hurts the possibility of real energy reform, but it activates, and hence strengthens, the conservative modes of thought that lie behind those proposals. The bottom line: A nuanced policy that looks like a rightward move has the cognitive effect of a rightward move. Cognitive effects matter awfully in presidential campaigns.

The domain of ECONOMY contains problems, which are central for the audience regardless of time and ideologies. In this sense, conceptual metaphors 'shape' the presidential debates.

For many decades, American presidential debates have worked out their own official style which became a tradition. It includes democratic procedures of collecting questions with the participation of the audience, strict timing of speech equal for each candidate. The genre of presidential debates is specified by the highest political rank of participants' roles, it is limited to situations of institutional communication and the range of the most urgent problems from the candidates' programs.

As any political discourse, debates include elements of antagonism and demonstration of power (Laclau \& Mouffe, 1985). However, a certain turn towards populism in the culture of the $21^{\text {st }}$ century, in general, reflected in the discourse of debates, too. The tendency to violate traditional 
procedures and a tangible degree of aggression seems to increase in the presidential debates of the latest few decades; it is drastically evident in the communicative behavior of President Trump.

Politeness principle to a great extend defines the results of debates and in particular helps create an attractive image of the candidate in the eyes of the audience. Still, Lakoff (2002, p. 375) argues that, in politics, 'perfect communication' does not work. "Different people have very different views of what constitutes polite conversation. For some people politeness means being indirect $<\ldots>$. For others politeness means directness" (Lakoff, 2002, p. 375-376).

In this paper, we treat impoliteness as a cognitive-communicative category, a linguo-cultural means of regulating communicative behavior; it is based on the linguo-cultural behavioral prescriptive concept-property of IMPOLITENESS, a pragmatic anti-concept and member of the antinomy politeness-impoliteness. There are five main impoliteness strategies in discourse (Shevchenko \& Petrenko, 2019). In presidential debates, impoliteness is mostly represented by at least three of them: the strategy of devaluation of the hearer (manifested by tactics of criticism and derogation), the strategy of unwarranted exclusion (tactics of distancing, hostility, avoidance of speech, unfriendliness, non-acceptance), and the strategy of unwarranted intrusion (tactics of disturbing and causing intended harm).

The strategy of imposition is not typical for presidential debates; it is mostly indirect:

(15) McCain: Well-well, let me give you an example of what Senator Obama finds objectionable, the business tax.

(The Commission on Presidential Debates, 2008)

In the $21^{\text {st }}$ century, overt intrusion manifested in crosstalk seems to become more and more frequent. In 2000 and 2004, we register one case of crosstalk per debate; in 2008, there were eight of them; in 2012 - twenty-eight; in 2016-nine, and in 2020, there were amazing seventy-three cases of crosstalk in one debate. In the discussion of Hunter Biden's income (16), unwarranted intrusion in the form of crosstalk between both candidates and the moderator is followed by multiple interruptions on behalf of the candidates:

(16) Trump: Hey, let me just tell you, Joe-

Biden: No, no. Mr. President- [crosstalk]

Trump: Three and a half million, Joe.

Biden: That is simply not true.

Trump: Why did he deserve three and a half million from Moscow?

Biden: Look, here's the deal. We want to talk about families and ethics. I don't want to do that. I mean, his family, we could talk about all night. His family's already-

Trump: My family-

Wallace: No, no- [crosstalk].

Trump: My family lost a fortune by coming down and helping us with governance.

Biden: And that's such a- [crosstalk]

Wallace: Mr. President-

Trump: Every single one of them lost a fortune-

Biden: This is not about my family or his family. It's about your family, the American people. [crosstalk] That's not true. It doesn't want to talk about what you need. You, the American people, it's about you. That's what we're talking about here. [crosstalk]

(The Commission on Presidential Debates, 2020)

Interruptions are not allowed by the debate procedure, so the moderator has to point this out to President Trump: 
(17) Wallace: We have six segments. $<\ldots>$ I think that the country would be better served, if we allowed both people to speak with fewer interruptions. I'm appealing to you, sir, to do that. (The Commission on Presidential Debates, 2020)

The procedure and style of political debates encourage candidates to demonstrate good manners and friendship, especially at the beginning of their discussion. In terms of politeness principle (Brown \& Levinson, 1988), this aim is reached by a negative politeness strategy of hedging (just) and positive politeness strategy of including both speaker and hearer into the activity (we both, equally, we are together):

(18a) Kerry: And I believe President Bush and I both love our country equally. But we just have a different set of convictions about how you make America safe.

(The Commission on Presidential Debates, 2004a)

(18b) Clinton: Finally, we tonight are on the stage together, Donald Trump and I. Donald, it's good to be with you. We're going to have a debate where we are talking about the important issues facing our country. You have to judge us ... (The Commission on Presidential Debates, 2016)

Devaluation of the hearer, mostly manifested implicitly in presidential debates (19a), becomes explicit in 2020, when it is realized through the tactics of derogation (conceptual metaphor CHARACTER IS BLOOD (19b)); compare:

(19a) Bush: That is going to be a big difference between my opponent and me.

(The Commission on Presidential Debates, 2000)

(19b) Trump: But I'll tell you, Joe, you could never have done the job that we did. You don't have it in your blood. You could've never done that, Joe.

(The Commission on Presidential Debates, 2020)

Calling names (BEHAVIOR OF THE CANDIDATE IS BEHAVIOR OF THE CLOWN (20a), conceptual metaphor of personification (20b)) is another example of devaluation of the hearer, not registered in presidential debates until recently:

(20) Biden: Well, it's hard to get any word in with this clown. Excuse me, this person. <...>

(20b)Trump: Well, you didn't do very well in Swine Flu. H1-N1, you were a disaster. Your own Chief of Staff said you were a disaster. $\quad$ (The Commission on Presidential Debates, 2020)

In 2020 presidential campaign, we register a rare for the discourse of debate strategy of unwarranted exclusion realized by the tactics of distancing in the form of the so-called 'silencers' (shut up, keep yapping) followed by interruption (I think we've ended this-):

(21) Biden: Will you shut up, man?

Trump: Listen, who is on your list, Joe? Who's on your list?

Wallace: Gentlemen, I think we've ended this-

Biden: This is so un-Presidential.

Trump: He's going to pack the court. He is not going to give a list.

Wallace: We have ended the segment. We're going to move on to the second segment.

Biden: That was really a productive segment, wasn't it? Keep yapping, man.

(The Commission on Presidential Debates, 2020)

In all of these examples, the persuasive and informative goals of presidential debates are reached by discourse strategies which demonstrate more and more changes in the procedure and style of debates. 


\section{Conclusion}

This paper focused on metaphoric conceptualizations of ECONOMY in American presidential debates of the $21^{\text {st }}$ century. This research was underpinned by a complex cognitive-pragmatic methodology and comprised two interconnected steps of analysis: a semantic cognitive and a communicative one. The former provided an opportunity to establish the semantic properties of lexemes in terms of a lexico-semantic field and, consequently, find out the concept structure of ECONOMY in terms of frames and domains, and single out its main metaphoric and metonymic models. The latter made it possible to define the leading discourse strategies in economic segments of presidential debates.

In the $21^{\text {st }}$ century American presidential debates, the most widely used conceptual metaphoric models of ECONOMY are personification, orientation, and structural models. The latter are dominated by conceptual metaphors ECONOMY IS AN ARTIFACT, ECONOMY IS A PLANT, ECONOMY IS MEDICINE, ECONOMY IS WAR, ECONOMY IS AN ANIMAL. Most cases of conceptual metonymy of ECONOMY highlight relations PART-FOR-WHOLE, LOCATION-FOR-INSTITUTION, and PERSON-FORINSTITUTION.

Discursive strategies and tactics in economic segments of presidential debates are modified by their persuasive, informative and manipulative goals. We claim that the presidential debates of the last two decades are characterized by the use of impoliteness strategies, which are treated as cognitive and communicative entities, embodied in the concept of IMPOLITENESS - a pragmatic (not ontological) regulative concept of communicative behavior, an anti-concept in the category POLITENESS / IMPOLITENESS. Such strategies become noticeable in modern political discourse on the whole, and in President Trump's communicative behavior, in particular.

The paper has opened the space for discussing the use of figurative language in political discourse and for adapting the methodology of cognitive pragmatics; the results obtained can promote cross-cultural and historical vectors in cognitive-pragmatic linguistics.

\section{REFERENCES}

Bara, B. (2010). Cognitive Pragmatics. The Mental Processes of Communication. Cambridge, MA: MIT Press.

Barcelona, A. (2000). Introduction. The Cognitive theory of metaphor and metonymy. In A. Barcelona (Ed.), Metaphor and metonymy at the crossroads: a cognitive perspective (pp. 1-25). Berlin: Mouton de Gruyter.

Carston, R. (2002). Thoughts and utterances. The pragmatics of explicit communication. Oxford: Blackwell.

Chouliaraki, L. (2000). Political discourse in the news: Democratizing responsibility or aestheticizing politics? Discourse \& Society, 11(3), 293-314. Retrieved September 1, 2020, from http://www.jstor.org/stable/42888319

Collins English Dictionary. (n.d.). Retrieved September 10, 2020, from https://www.collinsdictionary.com/dictionary/english

Coulson, S., \& Oakley, T. (2005). Blending and Coded meaning: Literal and Figurative Meaning in Cognitive Semantics. Journal of Pragmatics, 37(10), 1510-1536.

Culpeper, J. Impoliteness: using and understanding the language of offence. Retrieved November 1, 2020, from http://www.lancaster.ac.uk/fass/projects/impoliteness/bibliography.htm

Deignan, A. (2012). Figurative language in discourse. In H.-J. Schmid (Ed.), Cognitive pragmatics (pp. 437-462). Berlin etc.: Mouton de Gruyter.

Dijk, T.A. van. (2008). Critical discourse studies: a sociocognitive approach. In R. Wodak, \& M. Meyer (Eds.), Methods of critical discourse studies (pp. 63-85). London: Sage Publishing.

Fauconnier, G., \& Turner, M. (2002). The way we think: conceptual blending and the mind's hidden complexities. New York, NY: New York Basic Books.

Feldman, L., \& Price, V. (2008). Confusion or enlightenment? How exposure to disagreement moderates the effects of political discussion and media use on candidate knowledge. Communication Research, 35(1), 61-87. https://doi.org/10.1177/0093650207309362 
Foolen, A. (2019). Quo vadis pragmatics? From adaptation to participatory sense-making. Journal of Pragmatics, 145, 39-46.

Goncharova, T. (2009). Lingvisticheski orientirovannye metody issledovanija politicheskogo diskursa [Linguistically oriented methods of political discourse research]. Linguistica Bidgostiana, 6, 51-63 (in Russian).

Goncharova, T. (2010). Lingvisticheskij analiz argumentacii v politicheskom dialoge [Linguistical analysis of political dialog argumentation]. Linguistica Bidgostiana, 7, 59-72 (in Russian).

Horyna, O.V. (2008). Kohnityvno-komunikatyvni kharakterystyky amerykanskoho elektoralnoho dyskursu respublikantsiv [Cognitive and communicative characteristics of the American Republican electoral discourse] (Unpublished candidate dissertation). V. N. Karazin Kharkiv National University, Kharkiv, Ukraine (in Ukrainian).

Kövecses, Z. (2002). Metaphor: a practical introduction. New York: Oxford University Press.

Kövesces, Z. (2017). Levels of metaphor. In Cognitive linguistics, 28(2), 321-347.

Laclau, E., \& Mouffe, C. (1985). Hegemony and socialist strategy: towards a radical democratic politics [W. Moore, \& P. Cammack, Trans.]. London: Verso.

Lakoff, G. (1993). The contemporary theory of metaphor. In A. Ortony (Ed.), Metaphor and thought. (pp. 202-252). Cambridge: Cambridge University Press.

Lakoff, G. (1996). Moral politics: what conservatives know that liberals don't. Chicago, IL: University of Chicago Press.

Lakoff, G. (2002). Moral politics: how liberals and conservatives think. Chicago, IL: The University of Chicago Press.

Lakoff, G. (2011, May 25). The mind and the Obama magic. Retrieved from https://www.huffpost.com/entry/the-mind-and-the-obama-ma_b_111105

Lakoff, G. (2013, November 6). Obama reframes Syria: metaphor and war revisited. Retrieved October, 2, 2019, from https://www.huffpost.com/entry/obama-reframes-syriameta_b_3879335

Lakoff, G., \& Johnson, M. (1980). Metaphors we live by. Chicago, IL: Chicago University Press.

Lakoff, G., \& Johnson, M. (1999). Philosophy in the flesh: the embodied mind and its challenge to western thought. New York, NY: Basic Books.

Radden, G., \& Kövecses, Z. (1999). Towards a theory of metonymy. In K. U. Panther, \& G. Radden (Eds.), Metonymy in language and thought (pp. 17-59). Amsterdam: Benjamins.

Shevchenko, I. S. (2018). Tabloidnist' dyskursu amerykanskyh prezydentiv dvadtsiat pershoho stolittia [Tabloid nature of the $21^{\text {st }}$ century American presidential discourse]. Visnyk $K h N U$, 87, 62-68 (in Ukrainian).

Shevchenko, I. S. (2013). Strategija i taktika na predizbornija diskurs pri Dzhordzh Bush [Strategy and tactics of George Bush's electoral discourse]. Teoria i istorija na retorikata. Sofia: Univ. "St. Kl. Ohridski" Press (in Bulgarian).

Shevchenko, I., \& Gutorov, V. (2019). A cognitive-pragmatic perspective on apologies in English and Ukrainian discourse. In Lege artis. Language yesterday, today, tomorrow, 4(2), 301-341.

Schmid, H.-J. (2012). Generalizing the apparently ungeneralizable. Basic ingredients of a cognitivepragmatic approach to the construal of meaning-in-context. In H.-J. Schmid (Ed.), Cognitive pragmatics. Handbooks of pragmatics. Vol. 4 (pp. 3-22). Berlin etc.: Mouton de Gruyter.

Turner, M. (1996). Conceptual blending and counterfactual argument in the social and behavioral sciences. In P. Tetclock, \& A. Belkin (Eds.), Counterfactual thought experiments in world politics (pp. 291-295). Princeton, NJ: Princeton University Press.

Zhabotynskaya, S. A. (2013). Imja kak tekst: konceptual'naja set' leksicheskogo znachenija (analiz imeni jemocii) [The name as a text: conceptual network of lexical meaning (analysis of the name of emotion). Cognition, communication, discourse, 6, 47-76 (in Russian). 


\section{SOURCES FOR ILLUSTRATIONS}

The Commission on Presidential Debates. (2000). October 3, 2000 Transcript. Retrieved October 1, 2020, from https://www.debates.org/voter-education/debate-transcripts/october-3-2000-transcript/

The Commission on Presidential Debates. (2004a). September 30, 2004 Debate Transcript. Retrieved October 1, 2020, from https://www.debates.org/voter-education/debatetranscripts/september-30-2004-debate-transcript/

The Commission on Presidential Debates. (2004b). October 8, 2004 Debate Transcript. Retrieved October 1, 2020, from https://www.debates.org/voter-education/debate-transcripts/october-82004-debate-transcript/

The Commission on Presidential Debates. (2008). September 26, 2008 Debate Transcript. Retrieved October 1, 2020, from https://www.debates.org/voter-education/debatetranscripts/2008-debate-transcript/

The Commission on Presidential Debates. (2012). October 3, 2012 Debate Transcript. Retrieved October 1, 2020, from https://www.debates.org/voter-education/debate-transcripts/october-32012-debate-transcript/

The Commission on Presidential Debates. (2016). September 26, 2016 Debate Transcript. Retrieved October 1, 2020, from https://www.debates.org/voter-education/debatetranscripts/september-26-2016-debate-transcript/

The Commission on Presidential Debates. (2020). September 29, 2020 Debate Transcript. Retrieved November 1, 2020, from https://www.debates.org/voter-education/debatetranscripts/september-29-2020-debate-transcript/

Shevchenko Iryna-Doctor of Scinces (Linguistics), Professor, V.N. Karazin Kharkiv National University (4, Svobody Sq., Kharkiv, 61023, Ukraine); e-mail: iryna.shevchenko@karazin.ua; ORCID: 0000-0003-2552-5623

Шевченко Ірина Семенівна - доктор філологічних наук, професор, Харківський національний університет імені В.Н. Каразіна (майдан Свободи, 4, Харків, 61022, Україна); e-mail: iryna.shevchenko@karazin.ua; ORCID: 0000-0003-2552-5623

Шевченко Ирина Семеновна - доктор филологических наук, профессор, Харьковский национальный университет имени В. Н. Каразина (пл. Свободы, 4, Харьков, 61022, Украина); e-mail: iryna.shevchenko@karazin.ua; ORCID: 0000-0003-2552-5623

Goncharova Tamara - $\mathrm{PhD}$ in Linguistics, professor, Kazimierz Wielki University (Jana Karola Chodkiewicza 30,85-064, Bydgoszcz, Poland); e-mail: tamara.goncharova@ukw.edu.pl; ORCID: 0000-0002-5254-8006

Гончарова Тамара - кандидат філологічних наук, професор, університет Казимежа Великого (Jana Karola Chodkiewicza 30, 85-064, Бидгощ, Польща); e-mail: tamara.goncharova@ukw.edu.pl; ORCID: 0000-0002-5254-8006

Гончарова Tамара - кандидат филологических наук, профессор, университет Казимежа Великого (Jana Karola Chodkiewicza 30, 85-064, Быдгощ, Польша); e-mail: tamara.goncharova@ukw.edu.pl; ORCID: 0000-0002-5254-8006

Gutorov Volodymyr-PhD in Linguistics, Associate Professor, V.N. Karazin Kharkiv National University (4, Svobody Sq., Kharkiv, 61023, Ukraine); e-mail: gutorov@ karazin.ua; ORCID: 0000-0002-0399-5811

Гуторов Володимир Олександрович - кандидат філологічних наук, доцент, Харківський національний університет імені В.Н. Каразіна (майдан Свободи, 4, Харків, 61022, Україна); e-mail: gutorov@ karazin.ua; ORCID: 0000-0002-0399-5811

Гуторов Владимир Александрович - кандидат филологических наук, доцент, Харьковский национальный университет имени В.Н. Каразина (пл. Свободы, 4, Харьков, 61022, Украина); e-mail: gutorov@karazin.ua; ORCID: 0000-0002-0399-5811 